competence of pedagogical university students in Poland]: avtoref. dys. ... kand. ped. nauk: 13.00.04. Cherkasy. 24 [in Ukrainian].

Ohiienko, O. I. (2012). Andrahohichna kompetentnist pedahoha: tradytsii ta innovatsii u zarubizhnomu dosvidi [Andragogical competence of a teacher: traditions and innovations in foreign experience]. Osvita vprodovzh zhyttia: vymohy chasu. Kyiv: IPOOD NAPN Ukrainy. 194-198 [in Ukrainian].

Curriculum globALE. (2015). Global curriculum for Adult Learning \& Education. Authors (2nd Edition): M. Avramovska, T. Czerwinski, S. Lattke [Published by: Institute for International Cooperation of the German Adult Education Association (DVV International); German Institute for Adult Education Leibniz Centre for Lifelong Learning (DIE). DVV International, DIE; Warlich Mediengruppe, 43 [in English].

Jakimiuk, B. (2019). Profesjonalizacja nauczycieli dorosłych [Professionalization of Adult Educators]. Edukacja zawodowa i ustawiczna, 4, 187-203 [in Polish].

УДК 378.013.83

DOI: https://doi.org/10.35387/od.2(20).2021.72-80

Білик Вікторія Володимирівна

- кандидат педагогічних наук, старший викладач кафредри технологічної та професійної освіти $i$ декоративного мистецтва Хмельницького національного університету
Bilyk Viktoriia - Candidate of Pedagogical Sciences, Senior Lecturer of the Department of Technological and Professional Education and Decorative Arts of the Khmelnytskyi National University

ORCID iD: https://orcid.org/0000-0003-1265-3693

E-mail: bilykvika@ukr.net

\title{
МЕТОДИ АКТИВІЗАЦІЇ НАВЧАННЯ ЗДОБУВАЧІВ ВИЩОЇ ОСВІТИ МАГІСТЕРСЬКОГО РІВНЯ: З ДОСВІДУ ВИКЛАДАННЯ АНДРАГОГІКИ
}

\begin{abstract}
Анотація. У статті обгрунтовано актуальність використання методів активізації навчання при викладанні дисциплін у вищій школі. Навчання із використанням методів активізації полягає у взаємному партнерстві педагога і студентів, демократичному, діалогічному, заохочувальному стилі спілкування, максимальному підвищенні суб'єктності магістрів, спрямованості на продуктивну й творчу діяльність, формуванні соціальних навичок. Для підвищення ефрективності, результативності, мотивації та активізації навчальної діяльності здобувачів вищої освіти під час вивчення дисципліни «Андрагогіка» встановлено, що доцільним $\epsilon$ використання методів активізації навчання, які сприяють більш усвідомленому та ефективному формуванню результатів навчання, підвищенню інтересу до навчання, можливості аналізу власної та командної (групової), діяльності на занятті, посиленню ступеня об'єктивності оцінювання тощо.

Схарактеризовано особливості використання методів активізації навчання при вивченні здобувачами вищої освіти андрагогіки. Визначено, що
\end{abstract}


під час навчання магістрів дисципліні «Андрагогіка», ефективним буде використання таких методів активізації навчання: метод проєктів, кейсметод, ігрові методи та портфоліо. Метод проєктів полягає у розробленні здобувачами вищої освіти якісного кінцевого продукту, готового для впровадження. При розробленні проєкту у студентів фрормується досвід самостійного аналізу наукової літератури в галузі, відбувається здобуття знань та їх практичне застосування при вирішення завдань. Кейс-метод дозволяє реалізувати колективні форми навчання при вирішенні конкретних ситуацій, наближених до професійних. Ігрові методи передбачають імітацію студентами професійних дій шляхом гри за визначеними правилами. Різновидом ігрових методів, що сприяє фрормуванню практичних навичок у студентів є навчальний тренінг. Метод портфоліо полягає у фрормуванні власного портфоліо студента з дисципліни. Цей метод акцентує увагу на досягненнях студента, інтегрує кількісну та якісну оцінку із перевагою самооцінювання над зовнішнім оцінюванням.

Ключові слова: метод навчання; метод активізації навчання; андрагогіка; метод проєктів; кейс-метод; ігровий метод; портфоліо.

Bilyk Viktoriia

\section{METHODS OF LEARNING INTENSIFICATION FOR MASTER'S STUDENTS: FROM THE EXPERIENCE OF TEACHING ANDRAGOGICS}

Abstract. The article considers the importance of using methods of learning intensification while teaching disciplines at higher school. Learning based on methods of intensification is a mutual partnership of teachers and students that presupposes democratic, dialogic, encouraging style of communication, ultimate increase of Master's students' subjectivity, focus on productive and creative activities, the formation of social skills. It has been found out that to increase the efficiency, effectiveness, motivation and to intensify educational activities of higher school students during the study of the "Andragogics» discipline it is expedient to use methods of learning intensification that promote more conscious and effective learning outcomes, boost interest in learning, promote analysis of individual and team (group) activities in the classroom, increase the degree of assessment objectivity, etc.

The peculiarities of using learning intensification methods in the study of "Andragogics» by higher school students have been characterized. It has been determined that during the training of masters in the "Andragogics" discipline, it is effective to use the following methods of learning intensification: project method, case method, game methods and portfolio. The project method is aimed at developing by Master's students a high quality final product ready for implementation. While developing a project, students form the experience of independent analysis of scientific literature in the field, they acquire the knowledge and can practically apply it while solving problems. The case method allows to implement collective forms of learning in solving specific situations close to professional. Game methods involve students' imitation of professional actions by playing according to certain rules. One kind of game methods that contributes to the formation of students' practical skills is workshops. The method of portfolio is aimed at forming a student's own portfolio by the discipline. This method focuses on the student's achievements, integrates quantitative and qualitative assessment with the 
preponderance of self-assessment over the external assessment.

Key words: methods of learning; methods of learning intensification; project method; case method; game method; portfolio.

Постановка проблеми, її актуальність. У переліку навчальних дисциплін, що розміщені в університетському каталозі вибіркових дисциплін має місце дисципліна «Андрагогіка», метою вивчення якої $\epsilon$ набуття професійних знань, умінь, навичок, досвіду, що відповідають сутності і змісту діяльності навчання дорослих, вивчення наукової специфіки андрагогіки.

Забезпечення якості результатів навчання 3 дисципліни «Андрагогіка» поряд із удосконаленням змісту, вибором оптимальних форм і засобів навчання потребує використання методів активізації навчання. Використання методів активізації навчання під час вивчення андрагогіки сприяє тому, що здобувач вищої освіти стає активним суб'єктом навчального процесу, а викладач виконує функції організатора, консультанта, педагога-менеджера, режисера навчання, помічника, який створює умови для активної пізнавальної діяльності здобувачів.

Навчання із використанням методів активізації полягає у зміні особистісної позиції педагога, стилі управління, перевазі діалогічного стилю комунікативної та інтелектуальної діяльності, використанні нових способів соціальних і міжособистісних взаємодій, що направлені на спільну продуктивну й творчу діяльність; наявності аналітичного мислення у педагога; максимальному підвищенні суб'єктності магістрів, переході від пасивного сприйняття знань здобувачами вищої освіти до активного.

Ми підтримуємо думку С. Сисоєвої та А. Пегушина, що активному навчанню властиві такі специфічні принципи: розвиток особистості, активність студента, групова діяльність, гнучкий алгоритм та опора на позитивне (Сисоєва, 2011, с. 68), цілеспрямованість підготовки; випереджувальність навчання та його фундаменталізація; індивідуалізація та адаптивність навчання; самостійна творча робота з реальними завданнями і проблемами підвищеної складності (Пегушин, 2009, с. 84), що застосовуються разом із загальноприйнятими дидактичними принципами.

У Хмельницькому національному університеті з метою мотивації та активізації навчальної діяльності здобувачів вищої освіти на основі: встановлення суб'єктного типу взаємовідносин між учасниками освітнього процесу; домінування діалогічного, демократичного та рефлексивного стилів взаємодії між ними, впровадження групових та колективних форм організації освітнього процесу; використання проблемних, пошукових, евристичних та дослідницьких методів навчання, ефективних способів здобуття та засвоєння інформації, що орієнтовані на пошуково-мисленнєву та творчу діяльність 3 серпня 2019 р. чинним $€$ наказ ректора «Про активізацію впровадження інноваційних форм організації освітнього процесу та технологій навчання». У п. 2 вищезазначеного наказу вказується на необхідність активізації навчальної діяльності здобувачів вищої освіти при: проведенні лекційних занять використовувати різноманітні інтерактивні технології навчання (дискусії, 
проблемне навчання, «перевернуте» навчання тощо); проведенні практичних занять застосовувати різноманітні активні методи та технології навчання (кейсметод, ділові та дидактичні ігри, розв'язання проблемних завдань тощо); організації самостійної роботи здобувачів вищої освіти денної форми навчання запроваджувати відкриті масові он-лайн курси як елементи навчальної дисципліни (освітньої програми).

Аналіз актуальних досліджень і публікацій. Питання дослідження методів і технологій навчання, методики викладання стали об'єктом дослідження вітчизняних та закордонних науковців С. Батишева, О. Башкір, С. Гончаренка, В. Краєвського, Р. Мойсеєнко, Н. Науменко, О. Новікова, А. Пегушина та ін.

Мета статті - визначити і схарактеризувати оптимальні методи активізації навчання при викладанні дисципліни «Андрагогіка» для здобувачів вищої освіти магістерського рівня.

Виклад основного матеріалу дослідження. Як відомо, методи навчання визначають характер взаємодії між викладачем і здобувачами вищої освіти. Для отримання якісних результатів навчання з навчальної дисципліни «Андрагогіка» необхідно з переліку існуючих використовувати в навчальному процесі оптимальні дидактичні методи, що суворо визначаються рівнем цілей і умовами інфраструктури.

Теоретичні й емпіричні методи учіння та навчання студентів повинні лежати в основі процесу формування у майбутніх фахівців результатів навчання з дисципліни «Андрагогіка», разом з цим, необхідно посилити практичне спрямування навчання. Орієнтація навчального процесу при цьому має бути спрямована на студента, на формування у нього умінь аналізувати ситуацію, самостійно приймати рішення, виконувати професійні функції. Невідповідність чинної практики організації навчального процесу вимогам компетентнісного підходу потребує необхідності впровадження інноваційних методів навчання поряд 3 традиційними. Оскільки поширені у вищій школі традиційні методи навчання не у повній мірі використовують приховані можливості розвитку розумових якостей студентів та призводять до їх перевантаження. Для розвитку продуктивного мислення у здобувачів вищої освіти викладач повинен ставити перед ними проблеми, подібні реальним професійним, задавати питання відкритого типу, що дасть можливість майбутнім фахівцям виконувати професійні завдання пов'язані із створенням умов для успішного навчання і професійного розвитку дорослого населення у закладах формальної і неформальної освіти (Білик, 2015, с. 20-21).

Організація такого навчання студентів можлива за умови використання у практиці викладання «Андрагогіки» методів активізації навчання. Методи активізації навчання - це методи, за допомогою яких відбувається стимуляція пізнавальної діяльності здобувачів вищої освіти, що супроводжується високим рівнем їх активності. Вони дозволяють студентам у короткі терміни та із більшою ефективністю сформувати власні результати навчання та забезпечити усвідомлене формування необхідних дій. Перерахуємо особливості «активного навчання» майбутніх 
фахівців: вимушена активізація мисленнєвої діяльності; тривалий час активної діяльності; творча самостійність здобувачів вищої освіти при вирішенні нетипових завдань; підвищення ступеню мотивації та емоційності, що сприяє виробленню навичок активної взаємодії викладача зі студентами, $€$ засобом розвитку особистості, її соціальних навичок; аналіз та усвідомлене коригування власних дій і, як наслідок, запобігання помилок у роботі.

$\mathrm{Ha}$ сьогоднішній день досить популярним $€$ використання імітаційних (моделюючих) методів навчання або «активних» методів теоретичного навчання і «активних» методів практичного навчання, що у класифікації методів навчання за О. Новіковим, належать до емпіричних методів-операцій навчання. Специфріка імітаційних методів полягає у моделюванні в навчальному процесі різних ситуацій, що виникають у професійній діяльності. Виокремлюють два імітаційних методи: аналіз конкретної ситуації і вирішення ситуацій. Перевагами імітаційної (моделюючої) системи навчання, зазначає С. Батишев, є: діяльнісний характер навчання; організація колективної навчальної діяльності в якій формуються спілкування, мислення, рефлексія; використання колективу як засобу розвитку індивідуальності (Батишев, 2009, с. 165-166).

Із розглянутих С. Батишевим методів навчання для активної мисленнєвої, продуктивної діяльності студентів (Батишев, 2009, с. 178-180), визначимо такі, що, на нашу думку, забезпечують результативне навчання майбутніх фахівців: вирішення професійних завдань, виконання завдань творчого характеру, вправи на прийняття рішень у різноманітних ситуаціях.

Безумовно, методи володіють компенсаторними можливостями, тобто однієї дидактичної мети можливо досягти поєднанням різноманітних методів навчання. Але механічне перенесення в навчальний предмет методів, що добре зарекомендували себе в іншому навчальному предметі, $\epsilon$ неефективним, тому виникає питання вибору оптимальних методів навчання певній дисципліні. Вибір методів навчання певній дисципліні полягає у конструюванні методики навчання, завданням якої є дослідження нерозривно пов'язаних між собою аспектів: цілей навчання, змісту, процесу викладання і процесу учіння.

В. Загвязинський розглядає два шляхи, що призводять до педагогічно обґрунтованого вибору прийомів і методів навчання. Перший шлях пов'язаний з класифікацією методів і оперуванням результатами. Другий - з типами або методичними системами сучасного навчання, коли метод не береться ізольовано від інших елементів системи, а є засобом втілення певних цілей на основі наперед відомих специфічних закономірностей і механізмів (Загвязинський, 2001, с. 70). С. Гончаренко у педагогічній літературі описує чинники, що необхідно враховувати при виборі методів навчання, відтак, при виборі методів навчання андрагогіці слід звертати увагу на можливості конкретних методів у реалізації поставлених цілей і завдань заняття; відповідність методів специфіці навчальної дисципліни, змісту і формам організації навчання; особливості здобувачів вищої освіти; можливості педагога; зовнішні умови. Керуючись визначеними С. Гончаренком чинниками при виборі дидактичних методів, для викладання 
навчального матеріалу з дисципліни «Андрагогіка», обрано такі, що направлені на моделювання професійної діяльності у навчальному процесі, це: метод проєктів, кейс-метод, ігрові методи, портфоліо.

Використання методу проєктів полягає у створенні проєкту студентом або групою студентів згідно із поставленим викладачем завданням для отримання якісного кінцевого результату, готового для впровадження у життя. Ми підтримуємо думку О. Бондаренко у тому, що метод проєктів - це сукупність прийомів, дій студентів у їх певній послідовності для досягнення поставленого завдання, що було заздалегідь визначене, обґрунтоване і яке має бути оформленим у вигляді певного кінцевого продукту (Андрущенко, 2011, с. 176). Метою використання методу проєктів у навчальному процесі $€$ надання здобувачам вищої освіти можливості самостійно набувати комплекс знань, умінь, професійноважливих якостей, досвіду у вигляді складових компетентності, що забезпечують здатність вирішувати практичні завдання, пов'язані 3 майбутньою професійною діяльністю. У процесі розробки проєкту у студентів формуються уміння самостійного узагальнення думок науковців, передового досвіду в галузі майбутньої професійної діяльності, аналізу знань та їх практичного застосування.

Під час аудиторної або самостійної роботи студентів, організованої в умовах магістратури, використання кейс-методу передбачає реалізацію колективної форми навчання. Кейс-метод, або метод аналізу конкретних ситуацій - це метод навчання при якому здобувачам вищої освіти пропонується осмислити поставлену перед ними ситуацію, наближену до професійної, визначити проблему та вирішити її, актуалізуючи необхідний комплекс знань. Під час розв'язання кейсів студенти мають проаналізувати запропоновану ситуацію, розібратися в суті проблеми та запропонувати можливі шляхи іiї вирішення і вибрати найкращий. Кейси при цьому базуються на реальному фактичному матеріалі або ж максимально наближені до реальної ситуації.

Використання ігрових методів під час навчання передбачає імітацію виконання професійних дій у певних ситуаціях шляхом гри за певними правилами. На основі роботи П. Щербаня, виокремлено такі основі елементи ігрового методу: визначення проблеми; наявність ситуації (ролі) у якій відбувається розв'язання проблеми; дії, якими реалізується роль; ігрові предмети (Щербань, 2004, с. 29). Ознаками гри, на нашу думку, є: створення умов, що імітують реальну професійну діяльність, наявність проблемних ситуацій, колективна діяльність учасників гри, визначені етапи та час проведення гри, наявність елементів змагання, визначені критерії оцінювання гри.

Одним із різновидів ігрових методів $€$ навчальний тренінг, що максимально сприяє формуванню практичних навичок у здобувачів вищої освіти. Об'єктом тренінгу є конкретний вид діяльності, що передбачає напрацювання та засвоєння поведінкових навичок, ідей тощо. Перевагами тренінгового навчання $є$ максимальне наближення до реальних ситуацій та активізація здобувачів вищої освіти. Методичною особливістю навчального тренінгу є груповий характер, що потребує інтенсивної взаємодії між усіма 
учасниками навчального процесу (Сисоєва, 2011, с. 128-129).

Сутність методу портфоліо полягає в тому, що здобувач вищої освіти за завданням викладача обирає власне «досьє» роботи для самостійного виконання в аудиторіях та позааудиторно. Портфоліо студента, як зазначає Ю. Романенко, - це інструмент самооцінки особистісної пізнавальної роботи студента, рефлексії його діяльності, самоконтроль та самоперевірка власних досягнень, аналіз, аргументація та планування подальших дій, а також зміна особистісних успіхів (Романенко, 2012, с. 38). Використання методу портфоліо в процесі викладання полягає у зміщенні акценту із недоліків на досягнення у навчанні, інтеграцію кількісної і якісної оцінок, розвиток комунікативних здібностей та, зокрема, перевагою самооцінки студентів над зовнішнім оцінюванням. Після завершення вивчення дисципліни «Андрагогіка» студенти демонструють і захищають прилюдно в аудиторії розроблені портфоліо, що містять теоретичні та практичні розробки (есе, розв'язання кейсів, розроблені проєкти тощо).

Висновки і перспективи подальших досліджень. Відтак, для підвищення ефективності, результативності навчання здобувачів вищої освіти під час вивчення дисципліни «Андрагогіка» доцільним є використання методів активізації навчання, що сприяють більш усвідомленому та ефективному формуванню результатів навчання, підвищенню інтересу до навчання, можливості аналізу власної та командної (групової), діяльності на занятті, посиленню ступеня об'єктивності оцінювання тощо. За результатами наукового пошуку вважаємо, що під час вивчення магістрами дисципліни «Андрагогіка» ефективним буде використання таких методів активізації навчання: метод проектів, кейс-метод, ігрові методи та портфоліо. У перспективі доцільно здійснити теоретичне обґрунтування методики викладання дисципліни «Андрагогіка» у ЗВО.

\section{Список використаних джерел}

Андрущенко, В. П., Луговий, В.І. (2011). Психолого-педагогічні засади проектування інноваційних технологій викладання у вищій школі: монографія. Київ: Педагогічна думка.

Батышев, С. Я. (Ред.). (2009). Профессиональная педагогика: учеб. для студентов, обучающихся по педагогическим специальностям и направлениям. Москва: ЭГВЕС.

Башкір. О.І. (2018). Активні й інтерактивні методи навчання у вищій школі. Педагогіка та психологія, 60, 33-44.

Білик В.В.(2015). Формування проектувальної компетентності у майбутніх інженерів-педагогів швейного профрілю в процесі професійної підготовки : дис. ... канд. пед. наук : 13.00.04 / Хмельницький національний університет. Хмельницький, 2015. 379.

Загвязинский, В.И. (2001). Теория обучения: современная интерпретация : учеб. пособ. Москва: Академия.

Кремень В. Г. (Ред.). (2008). Енциклопедія освіти. Київ: Юрінком Інтер.

Мойсеєнко Р. М. (2017). Активізація пізнавальної діяльності майбутніх фахівців засобами активних методів навчання в умовах університетської освіти. Наукові записки. Серія «Педагогічні науки», 159, 97-103. 
Науменко, Н. В. (2021). Напрями вдосконалення методик викладання навчальних дисциплін магістрам освітніх, педагогічних наук. Теорія і практика управління соціальними системами, 2, 49-57.

Пегушин, А. А. (2009). Современные образовательные технологии как средство повышения эффективности обучения. Юридическая наука $и$ правоохранительная практика, 3 (9), 77-85.

Романенко, Ю.А. (2012). Портфоліо студента: дидактичний аспект Наукові записки НДУ ім. Гоголя. Психолого-педагогічні науки. 2. 38-40.

Сисоєва, С. О. (2011). Інтерактивні технології навчання дорослих: навч.-метод. посібник. Київ: ВД «ЕКМО»

Щербань П. М. (2004). Навчально-педагогічні ігри у вищих навчальних закладах : навч. посіб. Київ: Вища школа.

\section{References (translated and transliterated)}

Andrushchenko, V., Luhovyi, V. (2011). Psykholoho-pedahohichni zasady proektuvannia innovatsiinykh tekhnolohii vykladannia u vyshchii shkoli [Psychological and pedagogical principles of designing innovative teaching technologies in higher education]. K. : Pedahohichna dumka [in Ukrainian].

Batyshev, S. Ya. (ed.). (2009). Professionalnaya pedagogika: ucheb. dlya studentov, obuchayushchikhsya po pedagogicheskim spetsialnostyam i napravleniyam [Professional pedagogy]. M.: EGVES [in Russian].

Bashkir, O. I. (2018). Aktyvni y interaktyvni metody navchannya u vyshchiy shkoli [Active and interactiveteaching methods in higher education]. Pedahohika ta psykholohiya - Pedagogy and psychology, 60. 33-34 [in Ukrainian].

Bilyk, V. V. (2015). Formuvannia proektuvalnoi kompetentnosti u maibutnikh inzheneriv-pedahohiv shveinoho profiliu $v$ protsesi profesiinoi pidhotovky [Formation of design competence for future engineers-educators of sewing profile in the process of vocational training: (PhD Thesis)]. Khmelnytskyi: Khmelnytskyi natsionalnyi universytet, 2015. 379 [in Ukrainian].

Kremen, V. H. (ed.) (2008). Entsyklopediia osvity [Encyclopedia of Education]. Kyiv: Yurinkom Inter [in Ukrainian].

Mojsejenko R. M. (2017). Aktyvizacija piznavaljnoji dijaljnosti majbutnikh fakhivciv zasobamy aktyvnykh metodiv navchannja $v$ umovakh universytetsjkoji osvity [Activation of cognitive activity of future specialists by means of active teaching methods in the conditions of university education]. Naukovi zapysky - Scientific notes. Serija «Pedaghoghichni nauky», 159, 97-103 [in Ukrainian].

Naumenko, N. V. (2021). Naprjamy vdoskonalennja metodyk vykladannja navchaljnykh dyscyplin maghistram osvitnikh, pedaghoghichnykh nauk [Directions for improving the methods of teaching disciplines to masters of educational and pedagogical sciences]. Teorija $i$ praktyka upravlinnja socialjnymy systemamy - Theory and practice of social systems management, 2, 49-57 [in Ukrainian].

Pegushin, A. A. (2009). Sovremennyye obrazovatelnyye tekhnologii kak sredstvo povysheniya effektivnosti obucheniya [Modern educational technologies as a means of increasing the effectiveness of training]. Yuridicheskaya nauka i pravookhranitel'naya praktika - Jurisprudence and law enforcement practice, 3 (9). 77-85 [in Russian].

Romanenko, Yu. A. (2012). Portfolio studenta: dydaktychnyi aspekt [Student 
portfolio: didactic aspect]. Psychological and pedagogical sciences Psychological and pedagogical sciences, 2, 38-40 [in Ukrainian].

Shcherban, P. M. (2004). Navchalno-pedahohichni ihry u vyshchykh navchalnykh zakladakh : navch. posib [Educational and educational games in higher educational establishments]. K. : Vyshcha shkola [in Ukrainian].

Sysoieva S. O. (2011). Interaktyvni tekhnolohii navchannia doroslykh : navch.metod. posibnyk [Interactive technologies for adult learning]. Kyiv : VD «EKMO» [in Ukrainian].

Zagvyazinskiy V. I. (2001). Teoriya obucheniya: sovremennaya interpretatsiya : ucheb. posob. (dlya stud. vyssh. ped. ucheb. zavedeniy) [Learning theory: a modern interpretation]. M. : Akademiya [in Russian].

УдК 159.9: 331.54

DOI: https://doi.org/10.35387/od.2(20).2021.80-88

Іенатович Олена Михайлівна доктор психологічних наук, старший науковий співробітник, завідувач відділу психології праці Інституту педагогічної освіти $i$ освіти дорослих імені Івана Зязюна НАПН України
Ihnatovych Olena - Doctor of Psychological Sciences, Senior Researcher, Head of the Department of Labor Psychology of the Ivan Zyazyun Institute of Pedagogical and Adult Education of the NAES of Ukraine

ORCID iD: https://orcid.org/0000-0002-0588-0620

E-mail: lena_ignat70@ukr.net

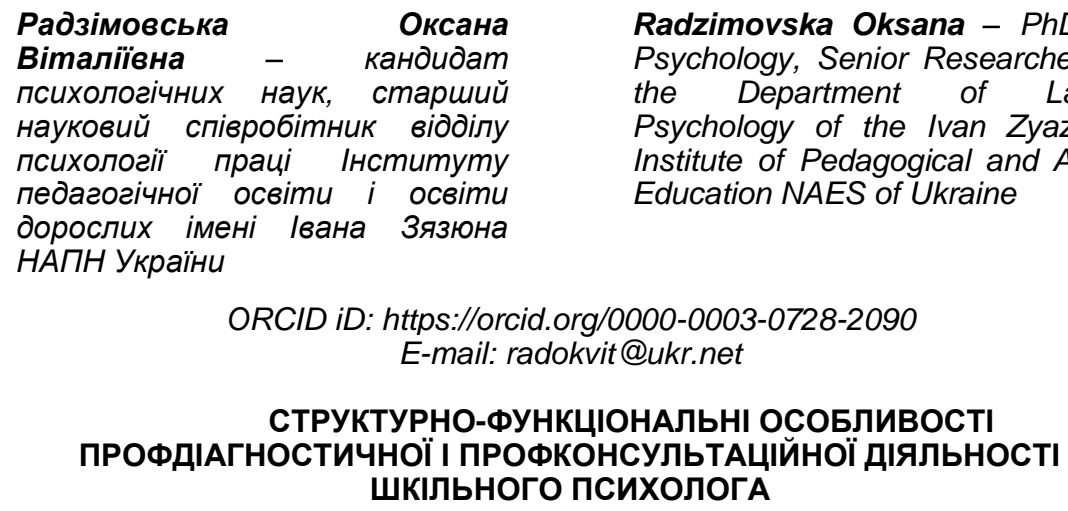

Анотація. В оглядовій статmі розглянуті особливості профрдіагностичної та профкконсультативної діяльності шкільного психолога, зокрема представлені психологічні аспекти професійного самовизначення особистості як провідної мети профдіагностичної та профоконсультаційної роботи психолога з учнями старших класів; розглянуті предмет, мета, завдання профрдіагностики і профоконсультації здобувачів загальної середньої освіти. 